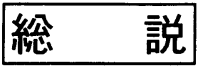

\title{
免疫系による卵巣機能調節
}

\author{
京都大学医学部婦人科学産科学教室 \\ 森崇 英, 福 岡 正 恒
}

\section{Immune Regulation of Ovarian Function}

\section{Takahide MORI and Masatsune FUKUOKA}

Department of Gynecology and Obstetrics, Faculty of Medicine, Kyoto University

Although it is well established that the pituitary gonadotropins and prolactin are the primary regulators of ovarian function, steroidal and nonsteroidal molecules produced locally in the ovary have been implicated in the modulation of gonadotropin action as autocrine or paracrine regulators. Recent studies suggest that the cells of the immune system play important roles in regulating ovarian function, and the immune regulation of ovarian function has become one of the topics in the field of ovarian physiology. Since it has become clear that the immune factors, cytokines, show a wide range of biological functions, not only on immune cells but also on nonimmune cells, the physiological significance of the resident immune cells, the widespread distribution of which in mammalian ovaries has been known for a long time, has reattracted attention as a third kind of regulator of ovarian function. In this article, current knowledge of the regulatory roles of immune cells as well as the cytokines in ovarian physiology is reviewed.

Key words : cytokine, steroidogenesis, granulosa cell, interleukin-1, tumor necrosis factor

\section{はじめに}

卵胞の発育・成熟 $\rightarrow$ 排卵 $\rightarrow$ 黄体形成 $\rightarrow$ 黄体退行といった卵巣の周期的変化と，それに伴う性ステ ロイドの産生は, 下垂体より分泌されるゴナドトロピン, プロラクチンにより endocrine regulation を受けていることは周知の事実であるが，近年こうしたゴナドトロピンの作用を卵巣 レベルで修飾するステロイド性・非ステロイド性の paracrine and autocrine regulators の存在が 知られるよらになってきた。この卵巣内局所調節に携わる細胞として, 卵胞を構成する顆粒膜細胞・ 萊膜細胞や黄体細胞といった卵巣細胞が当然挙げられるが，最近注目を集めているのが，免疫系細 胞の関与である。本稿では，こうした免疫因子による卵巣機能調節に関する最近の知見を述べる。

\section{1. 免疫系と卵巣との機能連関}

以前より，自己免疫疾患において卵巣炎による卵巣機能不全をしばしば伴らことや，胸腺欠損、 ウスで卵巣形成不全・機能不全がおこることが知られており，また性ステロイドが免疫細胞機能に 影響を与えることなどから，兔疫系と卵巣との機能連関が示唆されていた。 


\section{2. 卵巣における免疫系細胞の分布}

卵巣間質には，卵巣周期のあらゆる時期において単球/マクロファージ，リンパ球，顆粒球など が存在する ${ }^{1)}$ 。とくにマクロファージは卵巣間質に数多く存在し，その突起により卵巣細胞と接触 している像も観察される。退行黄体においては，マクロファージは変性した黄体細胞の筫食に携わっ ていると考えられてきた。卵胞については，その発育の初期段階では単球/マクロファージ以外の 免度系細胞は卵胞内には出現しない。しかし排卵前卵胞あるいは閉鎖卵胞には免度系細胞が急速に 流入する。排卵前卵胞において最も早く出現する免度系細胞は肥満細胞 (mast cell) である。排卵 現象は一種の炎症反応と考えられ，肥満細胞が LH サージによって脱顆粒をおこし，ヒスタミンを 遊離することが排卵現象の引金になると考えられている。同時に排卵前卵胞や形成期黄体からは, 好中球をはじめとする炎症細胞に対する遊走刺激因子が分泌され，そのシグナルにより集まる種々 の免疫系細胞が排卵や黄体形成，黄体機能維持に重要な役割を果たしている可能性がある。

\section{3. 実験モデルとしての顆粒膜細胞培養系について}

卵巣内局所調節機構の実験モデルとして, 卵胞の内層を構成するステロイド産生細胞である顆粒 膜細胞の培養系がしばしば用いられる。顆粒膜細胞は卵胞発育に伴って活発に増殖すると同時に, FSH，次いで LH に対する感受性を獲得して機能的に成熟していく。LHサージの発来により機能 的成熟をほぼ完了し，排卵後には黄体細胞（顆粒膜黄体細胞）へと形態的変化を遂げる。こうした 増殖と分化のさまざまな局面を in vitroにおいても再現することが可能である。とくにブタでは, 大きさの異なる卵胞（小・中・大）より，FSHレセプターのみ獲得した未成熟な細胞，LHレセ プターも獲得した細胞，LH サージ後の成熟細胞という，成熟度の異なる顆粒膜細胞を選別して採 取することが可能である。また，体外授精の採卵時に卵とともに得られるヒト顆粒膜細胞は，自然 周期の LH サージに相当する hCG 投与から約36時間後に採取されることから，ブタ大卵胞由来の 顆粒膜細胞同様，黄体形成期の顆粒膜黄体細胞に近い機能を有していると考えられる。

\section{4. 免疫系細胞による卵巣細胞の機能調節（in vitro）}

本来免废担当細胞であるマクロファージが in vitroにおいて, 卵巣細胞のステロイド産生に影響 を执よぼすことを最初に報告したのは, Kirsch ら (1981) 2)である。彼らはマクロファージとのcoculture により，マウス黄体細胞のプロゲステロン産生が充進すると報告した。この刺激にはマク ロファージと卵巣細胞との接触が必要であり，そのシグナル伝達物質はマクロファージ細胞膜上に 存在し, Concanavalin A (Con A) 刺激により培養液中に放出される蛋白と考学られた。ヒト黄体 化顆粒膜細胞の培養系においても，同様のマクロファージ/単球によるプロゲステロン産生刺激作 用が報告されている。一方，著者らの実験では単球による影響は追試しえず，対照的にリンパ球と ヒト黄体化顆粒膜細胞との co-culture で，プロゲステロンの産生充進がみられだ)。またマイト ショェンで刺激したリンパ球の培養上清中には，ヒト黄体化顆粒膜細胞のプロゲステロン産生（hC $\mathrm{G}$ 刺激時・非刺激時とも）を抑制する因子が検出されるとの報告もある。ブタあるいはラット顆粒 膜細胞についても，免度系細胞あるいはその培養上清によるステロイド産生への影響がいくつか報 告されているが, species や Con A 刺激の有無, あるいは顆粒膜細胞の成熟度等の実験条件により その影響（作用様式）はさまざまではある。

\section{5. サイトカインによる卵巣細胞の機能調節}

上記のような, 免疫系細胞による卵巣細胞機能調節のシグナル伝達には，おとらく多くの因子 （未知のものを含む）が関与していると思われる。近年, 免疫系のシグナル伝達物質であるサイト 
カインが免疫系のみならず，卵巣細胞を含む様々な組織あるいは細胞に対し，広汎な生物作用を示 すことがあきらかとなり，卵巣における局所調節因子としての存在意義が注目を集めている。種々 のサイトカインの同定や recombinant のサイトカインの開発とあいまって, サイトカインによる in vitro での卵巣機能調節に関する知見が集積しつつある。また，マクロファージはサイトカイン 以外に, TGF- $\alpha \cdot \mathrm{TGF}-\beta \cdot \mathrm{PDGF} \cdot \mathrm{EGF} \cdot \mathrm{FGF} ・ \mathrm{IGF}-1$ などの細胞増殖因子を分泌することが 知られており から，マクロファージによる卵巣細胞の機能調節は, サイトカインのみならず細胞増殖因子をも介 している可能性がある゙)。

既知のサイトカインのらちとくに注目されているのは, マクロファージ由来のインターロイキン 1 (IL-1) と腫瘍懷死因子 (TNF- $\alpha)$ である。

表1. 培養ブタ顆粒膜細胞に対する LL-1の作用

A. 增殖促進 ${ }^{* 1}$

1. 細胞数增加

2. $\left[{ }^{3} \mathrm{H}\right]$ thymidine incorporation

$\mathrm{TNF} ・$ 細胞增殖因子（EGF・FGF・insulin）之相乗作用あり

B. FSHによる分化 $(1-4)$ 抑制*2

1. aromatase 活性誘導

2.LH receptor 誘導

3. progesterone 産生

4.cAMP 産生

C. LH による分化（黄体化）抑制*3

1. 形態的黄体化

2.機能的黄体化 (progesterone 産生)

(機序)

1.cAMP 産生抑制

2.LH receptor 数减少

3. adenylate cyclase 活性阻害

D. Progesterone 基礎分泌抑制*1

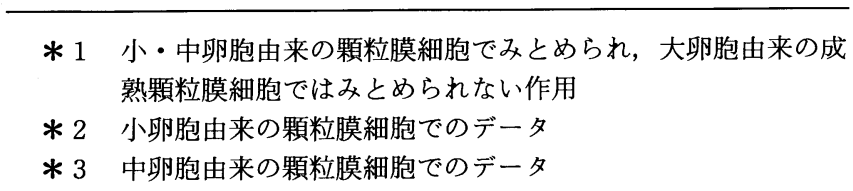

1) インターロイキン 1 (IL-1)

正常月経周期婦人の血中 IL-1活性が卵胞期より黄体期に高いことは以前から知られており ${ }^{6}$, 卵 巣機能と IL-1活性との関連が示唆されていた。単球/マクロファージのIL-1産生能は性ステロイ 
ドにより影響を受ける7)。プロゲステロン $10^{-9} \sim 10^{-8} \mathrm{M}$, エストラジオール $10^{-10} \sim 10^{-9} \mathrm{M}$ といら比較 的低濃度の刺激でヒト単球のIL-1産生は元進し，より高濃度では逆に抑制される。単球/マクロファー シのリポポリサッカライド（LPS）刺激によるIL-1 $\beta$ mRNA の発現も, プロゲステロン・エスト ラジオール濃度の上昇に伴い抑制される。また，体外授精時に採取したヒト卵胞液中には，かなり 高いIL-1活性がみとめられ8， その産生源は顆粒膜細胞ではないかと考えられている。

in vitroにおける，IL-1のブタ顆粒膜細胞に対する作用を表1に挙げた。IL-1は未熟な顆粒膜細 胞の増殖を促進 ${ }^{99}, \mathrm{FSH}$ による分化誘導を抑制する ${ }^{10)}$ とともに, LH 添加による形態的黄体化 （線維芽細胞様の細い形態から，黄体細胞に類似した，細胞質内に顆粒や脂肪滴を集積した上皮細 胞様形態への変化）と機能的黄体化（プロゲステロン産生の著明な増加）をも抑制する ${ }^{11}$ 。そのメ カニズムについては, LH レセプター数を減少させるとともに, adenylate cyclase に対しても直接 的な抑制作用をおよぼすためと考光られる ${ }^{12)}$ 。一方，cAMPによる A キナーゼの活性化からプロ ゲステロン産生に至るステップについては，有意な影響をおよぼさない。また，IL-1は種々の組 織において，プロスタグランディン（PG）の産生を刺激することが知られており， $\mathrm{PGF}_{2} \alpha$ は IL - 1 同様に LH による顆粒膜細胞の黄体化を抑制するが， PG 産生の抑制物質であるインドメサシンの 大量添加によっても IL-1の抑制作用は影響を受けないことから，黄体化に対する IL-1の作用は P Gを介したものではないと考えられる。

ラット顆粒膜細胞に対しても IL-1は，FSH 刺激時のエストラジオール，プロゲステロン産生， LH レセプターの誘導を抑制することが報告されている。またプロゲステロンの代謝産物である 20 $\alpha-\mathrm{OH}-\mathrm{P}$ の産生を増加させるところから，IL-1によるプロゲステロン分泌の減少は，少なくとも 部分的にはその代謝六進による可能性がある。なお， 2 種類の IL - 1, IL - $1 \alpha$ と IL-1 $\beta$ の抑制作用 について, ラットの顆粒膜細胞培養系では, IL-1 $\beta$ の方がょり少ない濃度で有効であると報告さ れているが，ブタの系では IL - $1 \alpha$ と IL - $1 \beta$ の効力に差はみとめられない。

卵胞の外層を構成する萊膜細胞に対するIL-1の作用については， ラットと八ムスターで相反す る報告がなされている。ラットでは $\mathrm{LH} / \mathrm{hCG}$ 刺激によるアンドロゲン産生を抑制すると報告され ているのに対し，ハムスターでは卵胞の器官培湌, 萊膜細胞の培養系において IL-1はプロゲステ ロン・テストステロンの産生を促進すると報告されている。

ヒト黄体化顆粒膜細胞のプロゲステロン分泌に対しては, in vitroで hCG を添加してプロゲス テロン分泌能を維持した場合は，ブタの大卵胞由来の顆粒膜細胞に対する作用同様，IL-1は影響 をおよぼさない注。これに対し，hCG 非添加時の基礎プロゲステロン分泌に対しては，促進的影 響をおよぼす。一方，FSH 刺激時のエストラジオール分泌に対しては，IL-1は抑制作用を示す。

2) 腫瘍懐死因子 (tumor necrosis factor - $\boldsymbol{a}, \mathrm{TNF}-\boldsymbol{a}$ )

卵巣における TNF- $\alpha$ の役割は, 黄体退行への関与と考えられてきた。黄体退行期にはマク口 ファージが著明に増加し，また退行期の黄体組織は in vitroにおいて，LPS 添加により容易に TN $\mathrm{F}$ を産生すること ${ }^{14)}$ から，マクロファージより産生された TNF- $\alpha$ が黄体の退行に関与している可 能性が指摘されている。一方, 免疫組織化学的手法により, ラット・ウシ顆粒膜細胞からも TNF$\alpha$ が産生されるといら報告がなされ，また体外授精の際に得られたヒ卜黄体化顆粒膜細胞の培養 液中にも TNF- $\alpha$ が検出されると報告されている。

ブタ顆粒膜細胞上には高親和性の TNF- $\alpha$ レセプターが存在し，そのレセプター数は FSH とイ ンスリンの同時添加により増加すると報告されている ${ }^{15)}$ 。ラットの顆粒膜細胞培養系において， $\mathrm{T}$ 
$\mathrm{NF}-\alpha$ はS FH 刺激によるプロゲステロン・エストラジオール産生, LH レセプターの誘導や種々 のステロイド合成酵素活性を抑制する ${ }^{16)}$ 。FSH 作用抑制の機序としては，FSH のレセプターへの 結合により活性化される adenylate cyclase 活性に対する阻害作用によると考えられている。ラッ 卜卵胞の器官培養系において TNFは，発育卵胞・閉鎖卵胞いずれに対しても，プレグネノロン・ プロゲステロン・20 $\alpha-\mathrm{OH}-\mathrm{P} ・ 17 \alpha-\mathrm{OH}-\mathrm{P}$ の産生を元進させる。この卵胞ステロイド産生に対 する TNF- $\alpha$ の促進作用は萊膜細胞を標的としたものであり, 実際分離した萊膜細胞に対して TN F- $\alpha$ は同様の促進作用を示す。ヒト黄体化顆粒膜細胞のステロイド産生に対する TNF- $\alpha$ の影響 は, IL- 1 と全く同様である ${ }^{13)}$ 。

3）インターフェロン(IFN)

IFN $\alpha$ は正常月経周期婦人への in vivo 投与により，ゴナドトロピン分泌には影響せずに，卵胞 期から排卵期のエストラジオール分泌と黄体期のプロゲステロン分泌を低下させると報告されてい る ${ }^{17)}$ 。ヒ卜卵胞液中には IFN 活性 $(10-36 \mathrm{U} / \mathrm{ml})$ が検出され，その活性は IFN $\gamma$ に対する抗体で 80 $\%$, IFN $\alpha$ に対する抗体で $20 \%$ 中和された ${ }^{18)}$ 。をた，自己免疫疾患に合併した早発卵巣不全 （premature ovarian failure）においては，顆粒膜細胞にクラスII タイプの組織適合抗原が発現す るが, in vitroにおいて IFN $\gamma$ によりヒト顆粒膜細胞にクラスII抗原が誘導され，クラス I 抗原も 増加する ${ }^{19}$ ところから, IFN $\gamma$ が自己免疫による卵巣機能不全の発生に関与している可能性が指摘 されている。

ラットの顆粒膜細胞培養系において, IFN- $\gamma$ は FSH 刺激時のプロゲステロン, $20 \alpha-\mathrm{OH}-\mathrm{P}$, エストラジオール，LH/hCG レセプターの誘導を抑制すると報告されている 顆粒膜細胞の培養系では, ヒト IFN- $\alpha$ 添加により, FSH 刺激時のプロゲステロン産生は抑制され るが，IL-1と異なり，エストラジオール産生（テストステロンからエストラジオールへの変換） は逆に増加する20)。また, IFNは, 他の多くの腫瘍・非腫瘍性細胞に対する影響同様, 未熟なブタ 顆粒膜細胞の増殖を抑制する ${ }^{200}$ 。七卜黄体化顆粒膜細胞培養系においては, IFN は IL-1・TNF と 異なり， LH/hCG 刺激時のプロゲステロン産生を抑制する ${ }^{13)}$ 。この IFN の抑制作用は $\alpha \beta \gamma$ いず れの IFNでもみられるが，IFN $\gamma$ が最も強力である。プロゲステロン基礎分泌. FSH 刺激による エストラジオール産生に対しても，IFN $r$ はやはり抑制作用を示す。

4）その他のサイトカイン

ラット顆粒膜細胞培養系に括いて，インターロイキン2（IL-2）は FSH 刺激時のプロゲステロン・ $20 \alpha-\mathrm{OH}-\mathrm{P}$ の産生を促進し，七ト黄体化顆粒膜細胞に対しては hCG 刺激時のプロゲステロン産 生を抑制するとの報告もあるが，こうした影響がみられないといら否定的データもあり，議論が分 かれている。IL-3については, ラット顆粒膜細胞培養系において, 見かけ上プロゲステロン産生 には影響しないが, $20 \alpha-\mathrm{OH}-\mathrm{P}$ の産生を元進させるとの報告がある。ブタ顆粒膜細胞の LH 刺激 時のプロゲステロン産生に対する種々のサイトカインの影響を比較検討した結果, IL-1・TNF・I FN が濃度依存的抑制作用を示したのに対し, IL-3・IL-6では $100 \mathrm{ng} / \mathrm{ml}$ といら高濃度ではじめて 有意な抑制効果が得られ，IL-2・G-CSF・M-CSF では影響をみとめなかった（図1）。 おわりに

免疫系による卵巣機能調節について, in vitroでのデータを中心に, 現在得られている知見を述 べた。免疫系はサイトカインや他のペプチドを介して卵巣細胞の機能調節に関与するとともに, 免 疫系もまたステロイドホルモン等を介して卵巣細胞による機能調節を受けている可能性がある5)。 
またサイトカインは視床下部からの GnRH 分泌や下垂体からのゴナドトロピン分泌にも影響をお よぼすことが知られており，こうした間接的作用により卵巣機能調節に関与している可能性もある。 卵巣細胞機能に対する免疫系細胞やサイトカインの影響は多彩であり, in vitroにおいてサイトカ イン同志あるいはサイトカインと細胞増殖因子との相互作用もみられる ところから，免疫系によ る性腺機能調節機構は，まだ同定されていない未知のサイトカインを含めた複雑なネットワークを 形成している可能性が大きい。今後の研究が待たれるところである。

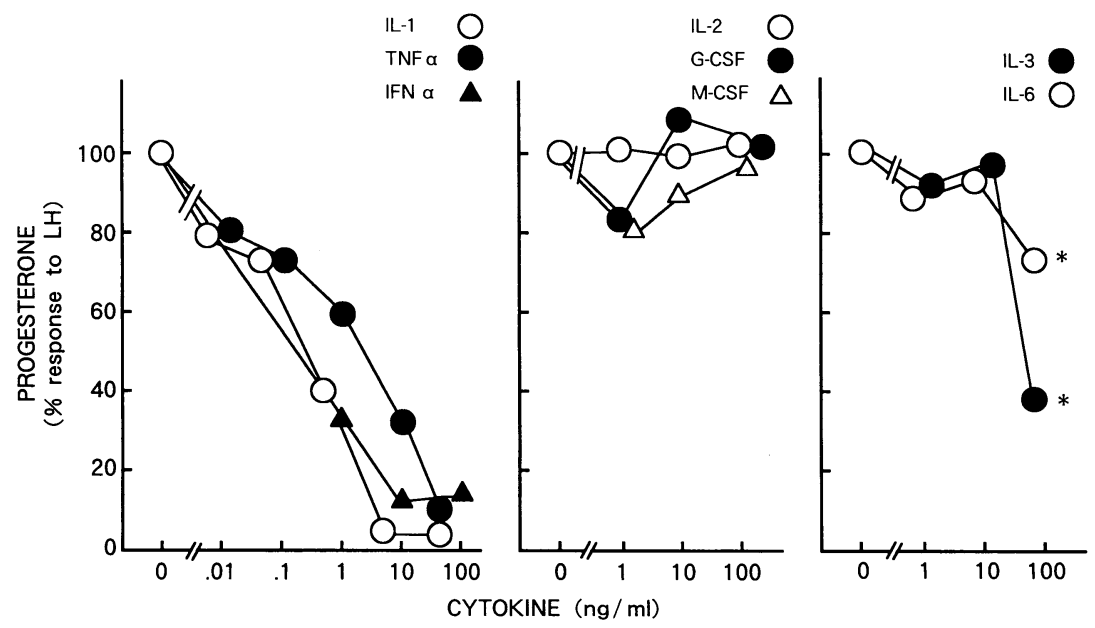

図1. ブタ顆粒膜細胞培養系における LH 刺激時のプロゲステロン産生に対する種々のサイトカイ ソの影響

文献

1) Adashi EY: The potential relevance of cytokines and growth factors to ovarian physiology: the emerging role of resident ovarian cells of the white blood cell series. Endocr Rev 1990; 11: 454-464

2 ) Kirsch TM, Friedman AC, Vogel RL, Flickinger GL: Macrophages in corpora lutea of mice: characterization and effects on steroid secretion. Biol Reprod 1981; 25:629-638

3 ) Emi N, Kanzaki H, Yoshida M, et al.: Lymphocytes stimulate progesterone production by cultured human granulosa luteal cells. Am J Obstet Gynecol 1991；165: 1469-1474

4 ) Rappolee DA, Mark D, Banda MJ, Werb Z: Wound macrophages express TGF- $\alpha$ and other growth factors in vivo: analysis by mRNA phenotyping. Science 1988; $241: 708$

5 ) Mori T: Immuno-endocrinology of cyclic ovarian function. Am J Reprod Immunol 1990; 23: 80-89

6) Cannon JG, Dinarello CA: Increased plasma interleukin-1 activity in women after ovulation. Science 1985; 227: 1247-1249

7 ) Polan ML, Daniele A, Kuo A: Gonadal steroids modulate human monocyte interleukin-1 (IL-1) activity. Fertil Steril 1988; 49: 964—968 
8) Khan SA, Schmidt K, Hallin P, Di Pauli R, De Geyter C, Nieschlag E: Human testis cytosol and ovarian follicular fluid contain high amounts of interleukin-1-like factor(s). Mol Cell Endocrinol 1988; 58: 221-230

9) Fukuoka M, Yasuda K, Taii S, Mori T: Synergistic actions of cytokines and growth factors in enhancing porcine granulosa cell growth. Endocrinol Jpn 1992; 39: 277-288

10) Yasuda $K$, Fukuoka $M$, Taii $S$, Takakura $K$, Mori $T$ : Inhibitory effects of interleukin - 1 on follicle-stimulating hormone induction of aromatase activity, progesterone secretion, and functional luteinizing hormone receptors in cultures of porcine granulosa cells. Biol Reprod 1990; 43: 905-912

11) Fukuoka M, Mori $T$, Taii $S$, Yasuda $K$ : Interleukin-1 inhibits luteinization of porcine granulosa cells in culture. Endocrinology 1988; 122: 367-369

12) Fukuoka $M$, Taii $S$, Yasuda $K$, Takakura $K$, Mori $T$ : Inhibitory effects of interleukin-1 on luteinizing hormone-stimulated adenosine $3^{\prime}, 5^{\prime}$-monophosphate accumulation by cultured porcine granulosa cells. Endocrinology 1989; 124: 884-890

13) Fukuoka M, Yasuda $K$, Emi $N$, et al.: Cytokine modulation of progesterone and estradiol secretion in cultures of luteinized human granulosa cells. J Clin Endocrinol Metab 1992; 75: 254-258

14) Bagavandoss $P$, Kunkel SL, Wiggins RC, Keyes PL: Tumor necrosis factor-a (TNF-a) production and localization of macrophages and $\mathrm{T}$ lymphocytes in the rabbit corpus luteum. Endocrinology 1988; 122: 1185-1187

15) Veldhuis JD, Garmey JC, Urban RJ, Demers LM, Aggarwal BB: Ovarian actions of tumor necrosis factor- $\alpha$ (TNF- $\alpha)$ : pleiotropic effects of TNF $\alpha$ on differentiated functions of untransformed swine granulosa cells. Endocrinology 1991; 129: 641-648

16) Adashi EY, Resnick CE, Croft CS, Payne DW: Tumor necrosis factor $\alpha$ inhibits gonadotropin hormonal action in nontransformed ovarian granulosa cells. J Biol Chem 1989; 264: 11591-11597

17) Kauppila A, Cantell K, Janne O, Kokko E, Vihko R: Serum sex steroid and peptide hormone concentrations, and endometrial estrogen and progestin receptor levels during administration of human leukocyte interferon. Int J Cancer 1982; 29: 291-294

18) Grasso G, Muscettola M, Traina V, Causio F, Fanizza G, Cagnazzo G: Presence of interferons in human follicular fluid after ovarian hyperstimulation for in vitro fertilization. Med Sci Res 1988; 16: 167-168

19) Gorospe WC, Tuchel $T$, Kasson BG: $r$-interferon inhibits rat granulosa cell differentiation in culture. Biochem Biophys Res Commun 1988; 157: 891—897

20) Yasuda K, Fukuoka M, Fujiwara H, Mori T: Effects of interferon on the steroidogenic functions and proliferation of immature porcine granulosa cells in culture. Biol Reprod (in press) 